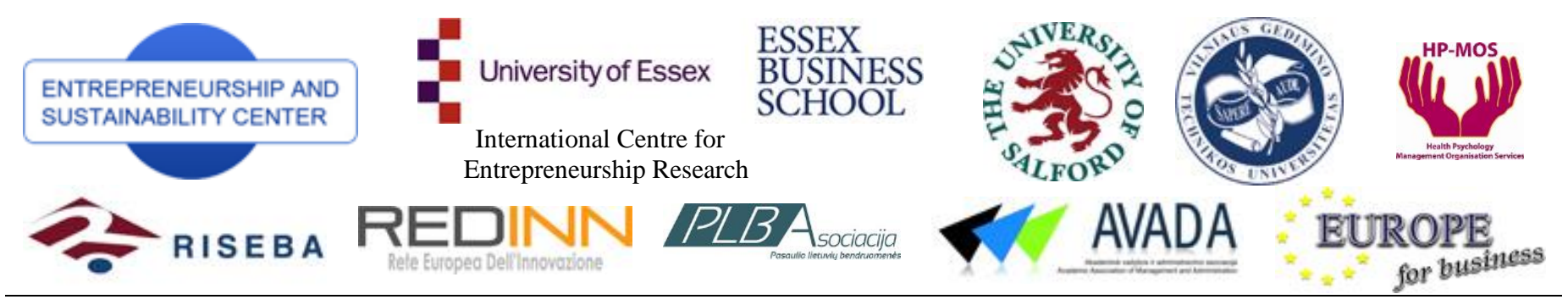

ENTREPRENEURSHIP AND SUSTAINABILITY ISSUES

ISSN 2345-0282 (online) http://jssidoi.org/jesi/aims-and-scope-of-research/

\title{
ANTI-CRISIS MANAGEMENT OF ENTERPRISES AS PRECONDITION OF SUSTAINABLE ENTREPRENEURSHIP
}

\author{
Kristina Garškaitè-Milvydienè \\ Vilnius Gediminas Technical University, Saulètekio al. 11, 10223 Vilnius, Lithuania \\ E-mail: kristina.garskaite@vgtu.lt
}

Received 27 February 2014; accepted 15 May 2014

\begin{abstract}
The paper examines the principles, stages and measures of enterprise anti-crisis management. Various interpretations of the concept of anti-crisis management are presented. The author supports the systemic treatment of enterprise anti-crisis management, when anti-crisis management is viewed as a complex of measures ranging from diagnostics of the financial condition of enterprises and their crisis to the development and implementation of special measures to prevent the critical condition. The content and concept of anti-crisis management are compared and linked with the concept of enterprise restructuring and its interpretations. The author describes the stages of enterprise anti-crisis management which can be implemented in the event of detecting negative trends in the activities of enterprises or when an enterprise faces a critical situation or when deciding on the continuity of its activities. An important role is played by the assessment of the financial condition of enterprises which can be performed using the express or comprehensive bankruptcy threat diagnostics. Such diagnostics allows for determination of the gravity of an enterprise's financial condition, that is, the stage of the crisis. The identified financial condition of the enterprise and its gravity determine the nature of the anti-crisis measures applicable to the enterprise. The implementation of an enterprise anti-crisis management plan must be accompanied by the control of the process.
\end{abstract}

Keywords: anti-crisis management of enterprises, restructuring, express and comprehensive diagnostics of enterprises bankruptcy threat, assessment, financial condition, crisis, solutions of overcoming critical condition, sustainable entrepreneurship

Reference to this paper should be made as follows: Garškaitė-Milvydienė, K. 2014. Anti-crisis management of enterprises and possibilities of overcoming their critical condition, Journal of Entrepreneurship and Sustainability Issues 1(4): 187-203.

DOI: http://dx.doi.org/10.9770/jesi.2014.1.4(1)

JEL Classifications: G32, G34, M19, M21

\section{Introduction}

As a result of the influence of a growing variety of national, international and specific foreign countries' factors, the business environment is becoming increasingly complex and uncertain almost daily. Multiple facets of secure and sustainable development emerge (Mačiulis, Tvaronavičienè 2013; Vosylius et al. 2013; Giriūnas, Mackevičius 2014; Wahl, Prause 2013) and affect performance of companies (Dudzevičiūtė 2013; Tvaronavičienė 2014; Laužikas, Krasauskas 2013; De Alencar, Almeida 2013). Sustainable entrepreneurship depends on a number of business decisions, including the key ones, are taken and implemented in enterprises without having accurate information about prospects either in the longer term or the near future. In order to 
reduce business risk, enterprises master and use in their activities the increasing number of advanced methods and measures of management (Laužikas, Mokšeckienè 2013; Wahl, Prause 2013; Laužikas, Krasauskas 2013). The concept 'anti-crisis management' has emerged relatively recently and is used increasingly often. The reason for its emergence is believed to have been economic reforms, swings of the economy and a large number of enterprises being on the verge of bankruptcy. An enterprise which does not stay in line with the 'environment' needs either to adapt and to make full use of its strengths or to disappear from the market. In the opinion of many entities and the State, in most cases an enterprise's bankruptcy is worse than its prevention. This determines the relevance of the anti-crisis management of enterprises. Anti-crisis management, if compared to corporate governance under normal conditions, is less researched into, just as are its specific methods and measures. In view of the features of anti-crisis management, compared with ordinary corporate governance, it may be claimed that it must carve its own 'niche' in the theory and practice of corporate (including financial) governance.

A study of the theoretical framework of anti-crisis management looks like having been commissioned by practitioners, given the fact that the need for enterprise anti-crisis management is observed not only in developing economies, but also in developed market economies. A special role in anti-crisis management is played by the area of financial management responsible for flows of funds and decision-making. Consolidation of financial management and control is vital for any enterprise, especially those found in a crisis situation. This article aims at analysing various approaches to this issue: the author presents an interpretation of the concept of anti-crisis management, its principles and stages, and the main methods of enterprise anti-crisis management. The main method used is a theoretical analysis of the issue based on conclusions and arguments presented in papers of foreign and Lithuanian researchers, and a generalisation of the content of anti-crisis management of an enterprise has been carried out.

\section{Concept of anti-crisis management}

Increased attention has recently been paid to anti-crisis management both in scientific literature and in practice. Some authors view enterprise anti-crisis management as enterprise management under the conditions of a general economic crisis, others - enterprise management on the eve of bankruptcy and yet others link the concept of anti-crisis management with the activities of the administrator within the framework of restructuring or even bankruptcy legal proceedings (Grant 2003; Brigham, Daves 2004; Altman, Hotchkiss 2006; De Pamphilis 2010; Aleksandrov 2010; Radionova 2011; Dallas 2012; Fosberg 2012; Baikovs, Zariňš 2013). Some authors argue that anti-crisis measures should be applied at the time when the financial condition of an enterprise operating in the market becomes critical, and the likelihood of its bankruptcy - real. Such a view ignores diagnostics of bankruptcy threat at the early stage of its occurrence and focuses exclusively on crisis 'treatment'. Some authors focus exclusively on crisis diagnostics and bankruptcy proceedings and completely forget about methods of anti-crisis management. Others argue that in anti-crisis management, it is essential to ensure such conditions that financial difficulties could not be of a permanent and stable nature (Goodhart 2006; Baldin et al. 2011; Bragg 2012; Brauer 2013; Baikovs, Zariņš 2013; Laužikas, Krasauskas 2013).

Economists describe anti-crisis management as activities intended for an enterprise to overcome a condition when a threat is posed to the functioning of the enterprise, and the enterprise's survival is considered as the main objective (Grant 2003; Korotkova 2009; Brauer 2013; Baikovs, Zariņš 2013; Wahl, Prause 2013). Such activities are characterised by an intensive and expeditious application of certain measures and methods designed to overcome the critical condition of the enterprise. In such cases, the focus is placed on the issues of the situation along with the speedy implementation of targeted measures (De Pamphilis 2010; Sakalas, Virbickaite 2011). Other authors emphasise the positive liberating aspect of the crisis, when the use of certain instruments allows to predict the approaching breakeven point and to change the emerging unfavourable situation (Brigham, Daves 2004; Baldin et al. 2011; Baikovs, Zariņ̌s 2013). Anti-crisis management places a particularly strong emphasis on the role of the time parameter (Dallas 2012; Brauer 2013; Baikovs, Zariňš 2013). According to it, the development and implementation of the measures intended for mitigation and overcoming of the crisis can be regarded as anti-crisis management in a narrow sense or in the short term. The cases when these measures are the measures of crisis 'prevention and therapy' can be seen as anti-crisis management in a broad sense or in the long term. 
In scientific literature, anti-crisis management is treated as the use of radical measures in order to survive (Ginevičius et al. 2005; Aleksandrov 2010). It should be noted that economics literature does not always use the term 'anti-crisis management'. Problems and their solutions are often described by providing methods intended to overcome the insolvency of an enterprise or to avoid its bankruptcy, rather than naming the process. Other authors focus in the anti-crisis management process on the relevance of assessment of the enterprise's financial condition and propose using for this purpose bankruptcy prediction models (Altman, Hotchkiss 2006; Huang et al. 2008; Mackevičius 2008; Mackevičius, Valkauskas 2010). The issue of anti-crisis management problem is most often primarily associated with the assessment of enterprises' financial condition (Tvaronavičienè 2001; Grigaravičius 2003; Mackevičius 2008; Bivainis, Garškaitė-Milvydienė 2011; Mažintienė, Burkšaitienė 2012; Baikovs, Zariņš 2013). Most authors supports the systemic treatment of enterprise anti-crisis management when anti-crisis management is viewed as a set of actions from the assessment of an enterprise's financial condition to the use of the methods of stabilisation or improvement of its condition.

While scientific literature examines a complex of actions which includes actions ranging from the identification of an enterprise's crisis to the application of methods of overcoming the crisis, the concept 'enterprise restructuring' is mentioned most frequently. The concept of enterprise anti-crisis management is associated with the concept of enterprise restructuring, because the processes pursue nearly the same goals of ensuring that an enterprise overcomes the crisis and survives and continues its successful operation. In scientific literature, enterprise restructuring is treated as actions of an enterprise designed to overcome a greater or lesser crisis, to restore the enterprise's operations and to increase their efficiency. Restructuring is also referred to as the totality of measures of corporate governance and transformation measures intended to obtain a synergy effect (Aleksandrov 2010; Brauer 2013; Wahl, Prause 2013). Others link restructuring to the rationalisation of an enterprise's activities in order to enhance the enterprise's competitiveness, to adapt to the changing environment and to increase the value of the enterprise (Ginevičius et al. 2005; Saboniene 2007; De Pamphilis 2010). The Lithuanian law describes restructuring of enterprises (Enterprises Resctructuring Law of the Republic of Lithuania 2001) as a resolution of insolvency issues. Restructuring allows enterprises to adapt to conditions of the market economy, operate profitably and be capable of competing at the national and international levels.

To summarise the mentioned concepts, it may be claimed that both enterprise anti-crisis management and restructuring are a whole complex of certain mutually interacting factors. In particular, enterprise restructuring is a variety of actions aimed at restoring an enterprise's operations and solvency, while anti-crisis management is a complex of actions ranging from the enterprise's financial condition diagnostics to the development and implementation of specific measures designed to improve the condition or to overcome the crisis. In such a way, anti-crisis management is a broader corporate governance system which is of a complex, or systemic, nature and focuses on ensuring a timely detection and prevention of the phenomena which adversely affect business and maintaining and improving the enterprise's position in the market subject to the development and implementation in the enterprise of a specific strategic programme.

\section{Principles of anti-crisis management}

Enterprise anti-crisis management is a system that includes the application of methods diagnosing enterprise bankruptcy threat and the implementation of measures overcoming the crisis (Grant 2003; Brigham, Daves 2004; Bivainis, Garškaite-Milvydienė 2011; Radionova 2011). The essence of such a system is that, when applying the enterprise's bankruptcy threat diagnostics, the critical condition is diagnosed at an early stage, which makes it possible to timely apply targeted anti-crisis measures or to justify the need for relevant restructuring procedures. Enterprises can timely diagnose the threat of bankruptcy, assess the extent of the critical condition, and make appropriate choice of measures overcoming the critical condition if in their activities the enterprises rely on the main principles of anti-crisis management (Grant 2003; Brigham, Daves 2004; Aleksandrov 2010; Bragg 2012) (Figure 1). Within the system of enterprise anti-crisis management, one of the key objectives is to periodically perform enterprise bankruptcy threat diagnostics in order to timely identify such threat.

1. Constant readiness to respond to possible disruptions in an enterprise's financial balance. The enterprise's financial condition changes. Possible changes at any stage of the enterprise's life cycle are determined by the 
enterprise's reaction to changes in the internal and external conditions of economic activities (Juchno, Tvaronavičienė 2004; Stundžienè, Bliekienè 2012). Some conditions determine a strong competitive position of the enterprise and its growing market price, while others can lead to a critical condition of the enterprise. Therefore, the enterprise must be constantly prepared for possible disruptions in the enterprise's financial balance.

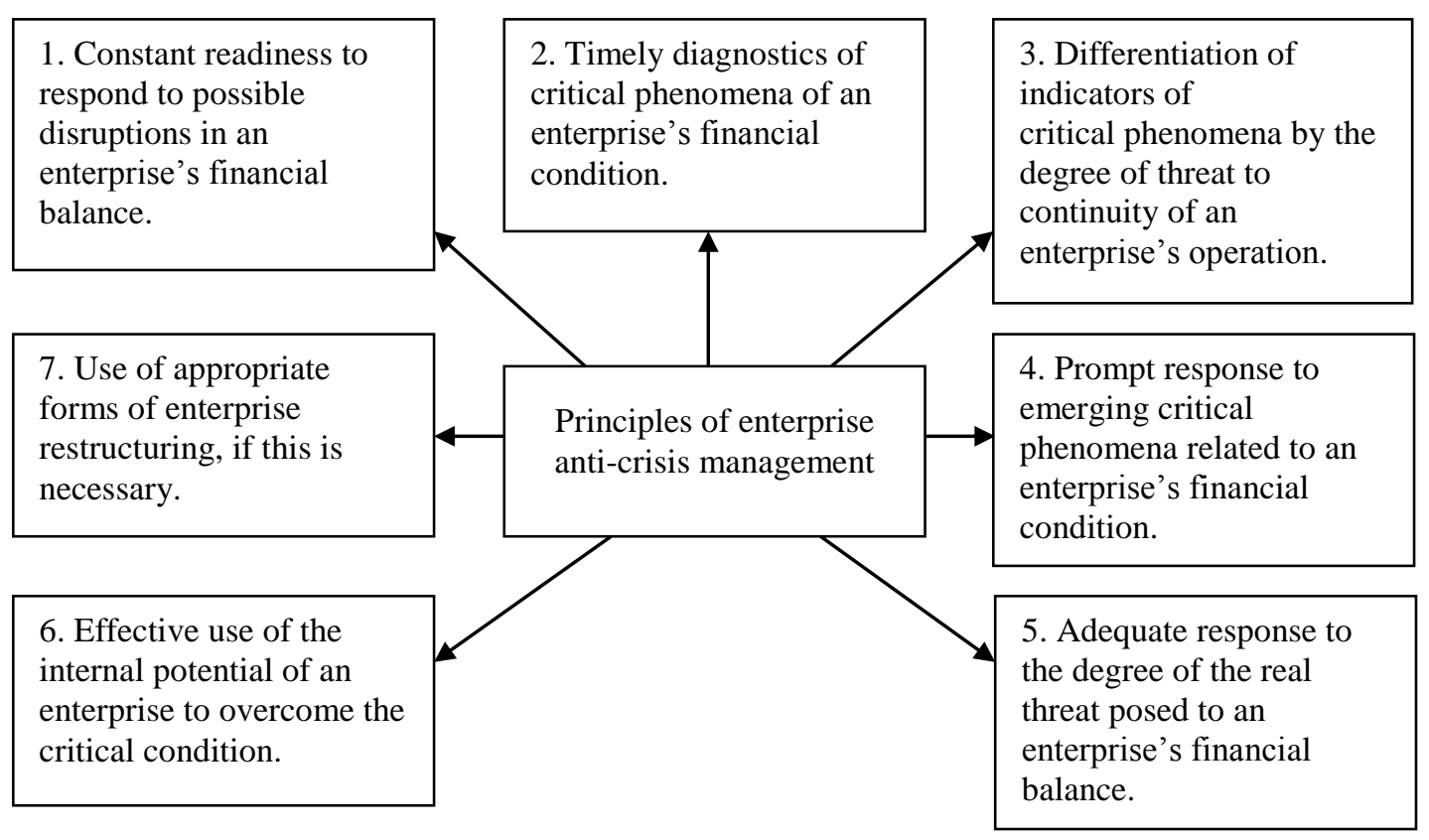

Fig.1. Basic principles of enterprise anti-crisis management

Source: compiled by the author

2. Timely diagnostics of critical phenomena of an enterprise's financial condition. When the threat of bankruptcy arises, the enterprise faces with the highest (catastrophic) financial risk associated with losses incurred by capital holders and creditors. In order to timely use all bankruptcy prevention possibilities, the threat of bankruptcy must be diagnosed at the early stages of the crisis.

3. Differentiation of indicators of critical phenomena by the degree of threat to the continuity of an enterprise's operation. Bankruptcy diagnostics makes use of a number of critical condition indicators. These indicators reflect various aspects of the enterprise's financial condition. Therefore, it is necessary to group the indicators of the critical phenomena by the degree of threat posed to the continuity of the enterprise's operation.

4. Prompt response to individual critical phenomena related to an enterprise's financial condition. Each emerging critical phenomenon tends to develop in every new operation cycle of the enterprise and also leads to new critical phenomena (Grant 2003; Brigham, Daves 2004). Therefore, the sooner anti-crisis management mechanisms are applied to each diagnosed critical phenomenon, the more opportunities will be available to the enterprise to restore the disrupted financial balance.

5. Adequate response to the degree of the real threat posed to an enterprise's financial condition (crisis stage). A system of measures used to prevent an enterprise's bankruptcy, usually linked with financial costs and losses resulting from a reduction in the scope of activities, termination of the implementation of investment projects, etc. The level of such costs and losses directly depends on the relevance of anti-crisis management measures and the scope of their application. The use of individual measures depends on the enterprise's current critical condition and must be commensurate with the degree of the threat of bankruptcy (Brigham, Daves 2004; Aleksandrov 2010). Otherwise, either the desired effect will not be achieved (if measures prove to be insufficient) or the enterprise will incur unreasonably high costs (if the measures prove excessive for the degree of the threat of bankruptcy). 
6. Effective use of the internal potential of an enterprise to overcome the critical condition. The threat of an enterprise's bankruptcy can be neutralised by using the enterprise's internal anti-crisis management measures, i.e., by using the enterprise's financial resources. In such a manner, the enterprise can avoid restructuring (external measures). Especially in the early stages of the crisis, the enterprise has a possibility of making effective use of internal financial resources.

7. Use of appropriate forms of enterprise restructuring, if this is necessary. If the threat of bankruptcy is diagnosed only in the late stage of the crisis and is very high and internal measures of enterprise anti-crisis management prove incapable of restoring an enterprise's financial balance, the enterprise must initiate restructuring and select the most appropriate form of such restructuring (Grant 2003; Brigham, Daves 2004; Aleksandrov 2010). This measure, designed to prevent imminent bankruptcy, is an extreme one within the framework of enterprise anti-crisis management.

These principles form a basis for the organisation of an enterprise's anti-crisis management. Anti-crisis management is based on the mentioned principles, which distinguish anti-crisis management from ordinary corporate governance.

\section{Main stages of anti-crisis management}

In order to overcome the critical condition, an enterprise needs, on the basis of the main principles of anti-crisis management, to develop a specific action plan in line with the stages of enterprise anti-crisis management (Grant 2003; Brigham, Daves 2004; Mackevičius 2008; Korotkova 2009; De Pamphilis 2010; Baldin et al. 2011; Sakalas, Virbickaitè 2011; Valackienė 2011; Bragg 2012; Ginevičius, Podviezko 2012; Krušinskas 2013) (Figure 2).

\section{Stages of anti-crisis management}

1. Periodic analysis of an enterprise's financial condition in order to enable early detection of the crisis.

2. Determination of the stage of an enterprise's crisis.

3. Examination of the main factors determining an enterprise's crisis.

4. Identification of an enterprise's objectives intended to overcome the critical condition and being commensurate with the stage of the crisis.

5. Selection and application of effective internal measures of an enterprise's financial stabilisation commensurate with the stage of the crisis.

6. Selection and application of effective restructuring forms.

7. Control of the implementation of the enterprise's measures intended to overcome the critical condition.

Fig.2. Main stages of enterprise anti-crisis management

Source: compiled by the author 
1. Periodic analysis of an enterprise's financial condition in order to enable early detection of a crisis. The system of the analysis of the enterprise's financial condition identifies certain financial indicators (groups of indicators) in respect of the threat of bankruptcy, with their negative changes indicating a greater or lesser threat of bankruptcy (Mackevičius 2008; Korotkova 2009).

2. Determination of the stage of an enterprise's crisis. After performing an analysis and detecting major deviations from the normal financial condition, the established financial strategy and system of standard financial indicators, the extent of the enterprise's critical condition is determined, that is, the stage of the crisis. The determination of the stage of the enterprise's financial crisis by means of appropriate methods of financial analysis allows for the development of a system of the relevant measures intended to prevent bankruptcy.

3. Examination of the main factors determining an enterprise's crisis. To this end, the following tasks need to be performed:

- preliminary grouping of factors according to the key descriptive characteristics;

- analysis of the extent of the impact of individual factors on the scope and nature of the enterprise's critical condition;

- forecasting of the tendencies related to the factors having an adverse effect.

4. Identification of an enterprise's objectives intended to overcome the critical condition and being commensurate with the stage of the crisis. The objectives of the enterprise's anti-crisis management are specified depending on the stage of the enterprise's critical condition. When identifying the objectives, account is taken of the forecasts of trends concerning the main factors affecting the threat of the enterprise's bankruptcy. Considering these conditions, it is possible to identify three principal objectives of the enterprise commensurate with the extent of the enterprise's critical condition (Grant 2003; De Pamphilis 2010; Bragg 2012):

- restoration of the enterprise's solvency;

- restoration of the enterprise's financial stability (with a view to achieving the enterprise's financial balance in the short term);

- change of the enterprise's financial strategy with a view to maintaining the enterprise's continuous economic growth (with a view to achieving the enterprise's financial balance in the long term).

5. Selection and application of effective internal measures of an enterprise's financial stabilisation commensurate with the stage of the crisis. The internal financial stability measures must be prompt and effective and designed to restore the solvency and financial balance of the enterprise using internal resources (Grant 2003; Brigham, Daves 2004; Baldin et al. 2011; Dallas 2012).

6. Selection and application of effective restructuring forms. If the critical condition of an enterprise is such that it cannot be overcome using internal financial resources, then the enterprise is forced to look for external assistance - in most cases, it needs to undergo restructuring. The enterprise can be restructured both by instituting restructuring proceedings and without them. The selected form of restructuring must be effective so that, within the shortest possible period of time, it would be possible to restore the enterprise's financial stability and to prevent bankruptcy. The form of restructuring describes the mechanism by means of which its objectives are achieved. The objectives of enterprise restructuring are achieved by implementing certain measures. Forms of restructuring can be selected within the framework of a specific area of restructuring having regard to the characteristics of the enterprise's critical condition. Forms/measures of enterprise restructuring can be divided into two main groups (Grant 2003; Brigham, Daves 2004; Grigaravičius 2003; Ginevičius et al. 2005; De Pamphilis 2010; Baldin et al. 2011):

- enterprise restructuring which focuses on the refinancing of an enterprise's debt;

- enterprise restructuring which focuses on the transformation of an enterprise (reorganisation, merger, scission).

7. Control of the implementation of an enterprise's measures intended to overcome the critical condition. The results of such control are discussed periodically in order to make the necessary adjustments and to determine the effectiveness of anti-crisis management measures. 


\section{Assessment of the financial condition of enterprises}

The critical factors of the financial condition of enterprises need to be evaluated, and the threat of bankruptcy predicted before the first signs of bankruptcy emerge. Such assessment and prediction of enterprise bankruptcy constitute a framework for enterprise bankruptcy threat diagnostics, which enables to develop and implement a strategy for enterprise anti-crisis financial management (prevention of enterprise bankruptcy). Enterprise bankruptcy threat diagnostics enables to determine a specific economic cause of the potential collapse of enterprises and provide proposals as to how to overcome it. A timely and comprehensive diagnostics of the threat of enterprise bankruptcy can help to prevent bankruptcy, because its results create preconditions for a more effective management of an enterprise's financial resources. Based on the results of the enterprise's bankruptcy threat diagnostics, balanced decisions regarding the enterprise's activities are made, available resources are assessed, trends of their use are determined, and further development of the enterprise is predicted (Grant 2003; Mackevičius 2008; Fosberg 2012). Enterprises with well-organised analytical activities are capable of detecting an imminent crisis at an earlier stage, offering a quicker response and reducing the threat. An analysis of literature (Brigham, Daves 2004; Goodhart 2006; Mackevičius, Valkauskas 2010; Bivainis, Garškaitè-Milvydienė 2011; Ginevičius, Podviezko 2011; Bragg 2012; Mažintienė, Burkšaitienė 2012; Krušinskas 2013; Valkauskas 2013 and etc.) shows that in solving this problem, a consistent enterprise bankruptcy threat diagnostic system is required, which would make it possible to comprehensively assess the enterprise's financial condition. An enterprise bankruptcy threat diagnostic system is a retrospective, present-day oriented and prospective study of an enterprise's activities that consists of the assessment of the enterprise's financial condition. Based on the assessment, critical factors of the enterprise's activities determining the enterprise's crisis or bankruptcy, as well as the extent of the enterprise's crisis and possibilities of overcoming the crisis of the enterprise are identified (Ginevičius et al. 2005; Aleksandrov 2010; Dallas 2012). Depending on goals and the methods employed, enterprise bankruptcy threat diagnostics can be of the following types: express enterprise bankruptcy threat diagnostics or comprehensive enterprise bankruptcy threat diagnostics.

\subsection{Express enterprise bankruptcy threat diagnostics}

Express enterprise bankruptcy threat diagnostics is a targeted financial analysis performed using data of financial statements of enterprises and corresponding standard algorithms of analysis. The main goal of express enterprise bankruptcy threat diagnostics is to determine in advance the critical factors of enterprises' activities and to assess the gravity of the critical condition of the enterprises.

\begin{tabular}{|l|}
\hline $\begin{array}{l}\text { 1. Selection of the crisis indicators capable of indicating the threat of } \\
\text { bankruptcy. }\end{array}$ \\
$\qquad \begin{array}{l}\text { 2. Development of a system of indicators for assessment of the threat of } \\
\text { an enterprise's bankruptcy. }\end{array}$ \\
\hline 3. Methods of analysis of enterprises in the critical condition. \\
\hline 4. Assessment of an enterprise's financial condition. \\
\hline
\end{tabular}

Fig.3. Main stages of express enterprise bankruptcy threat diagnostics

Source: compiled by the author 
Express bankruptcy threat diagnostics consists of four main stages (Bernstein 2000; Brigham, Daves 2004; Altman, Hotchkiss 2006; Juozaitienè 2008; Korotkova 2009; Bragg 2012; Fosberg 2012) (Figure 3).

1. Selection of the crisis indicators capable of indicating the threat of bankruptcy. Under present-day economic conditions, virtually all factors of an enterprise's financial condition can lead to the threat of bankruptcy. Therefore, the crisis indicators subject to an analysis must include the key items which may reflect the threat of the enterprise's bankruptcy. Potential indicators of the enterprise's crisis (Huang et al. 2008; Mackevičius 2008, Fosberg 2012) are presented in Figure 4.

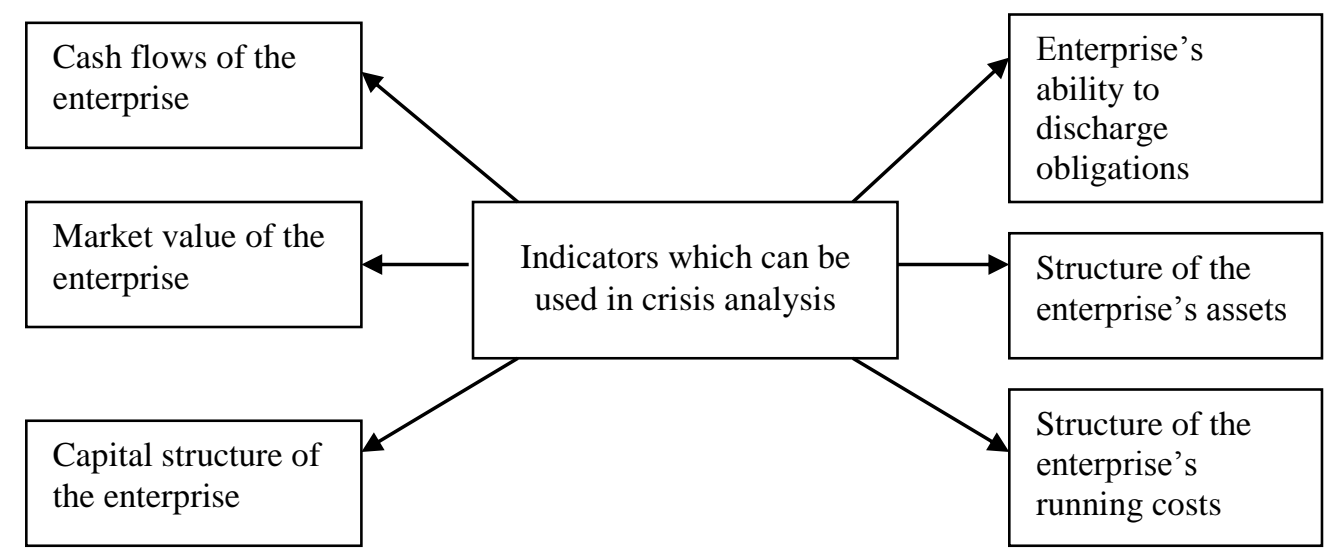

Fig.4. Indicators which can be used in enterprise crisis analysis

Source: compiled by the author

2. Development of a system of indicators for assessment of the threat of an enterprise's bankruptcy. The system of such indicators is developed based on each object of the crisis analysis. All indicators can be divided into absolute (expressed in absolute terms) and relative (expressed in relative terms) ones, which are selected for each specified object of the analysis.

3. Methods of analysis of enterprises in the critical condition. This analysis is based on the comparison of actual financial indicators against normative ones and determination of the dynamics of their deviations. The increase in dynamics of negative deviations shows the growth of critical phenomena in relation to an enterprise's financial position and the threat of bankruptcy. For the purposes of the analysis of specific areas of the enterprise's financial condition, the following traditional methods are employed (Mackevičius 2008; Juozaitienè 2008; Vendramin et al. 2010; Sakalas, Virbickaitė 2011; Didenko et al. 2012; Valkauskas 2013):

- horizontal financial analysis;

- vertical financial analysis;

- comparative financial analysis;

- financial risk analysis;

- integral/structural financial analysis (DuPont model);

- other models of analysis of financial indicators (bankruptcy forecast models).

4. Assessment of an enterprise's financial condition. This assessment is performed using crisis indicators and taking account of the results of the preceding stage. The examination of the objects under analysis allows for description of the extent of the enterprise's critical financial condition. The following stages/extent of the crisis and crisis mitigation measures are usually determined (Grigaravičius 2003; Korotkova 2009; Vendramin et al. 2010; Bivainis, Garškaitė-Milvydienė 2011; Sakalas, Virbickaite 2011; Valkauskas 2013):

1) minor financial crisis (in the event of the enterprise's minor financial crisis, it is necessary to stabilise the enterprise's current financial condition by applying internal measures);

2) severe financial crisis (in the event of the enterprise's severe financial crisis, it is necessary to implement a set of internal and external measures of stabilisation of the enterprise's financial condition);

3) financial catastrophe (in the event of the enterprise's financial catastrophe, it is necessary to apply effective forms of the enterprise's restructuring or to liquidate it).

If necessary, each of these stages can be further differentiated. 
A system for express enterprise bankruptcy threat diagnostics enables to identify the signs of a crisis in an enterprise's activities and the degree of gravity of the critical condition. The system has a particularly immense effect when the enterprise experiences only a minor financial crisis. In the event of a more extensive financial crisis, express enterprise bankruptcy threat diagnostics is not sufficient, and a comprehensive enterprise bankruptcy threat diagnostics needs to be performed.

\subsection{Comprehensive enterprise bankruptcy threat diagnostics}

Comprehensive enterprise bankruptcy threat diagnostics is usually performed in the event of a more extensive financial crisis, which can be determined during the performance of express bankruptcy threat diagnostics (Brigham, Daves 2004; Mackevičius 2008; Baldin et al. 2011; Bragg 2012). Comprehensive diagnostics means a system for the assessment of factors of an enterprise's critical condition by means of the methods of financial analysis and forecasting. The key objectives of comprehensive diagnostics are as follows (Bernstein 2000; Brigham, Daves 2004; Gibson 2008; Mackevičius 2008; Sakalas, Virbickaitė 2011; Brauer 2013):

- to revise the results of the assessment of the critical factors of an enterprise's financial condition obtained upon performing express enterprise bankruptcy threat diagnostics;

- to confirm the preliminary assessment of the gravity of an enterprise's critical condition;

- to forecast the development and consequences of individual factors affecting the rise of the threat of enterprise bankruptcy;

- to assess and predict the capabilities of enterprises to neutralise the threat of bankruptcy by using the internal financial potential of enterprises or resorting to external assistance.

The main stages of comprehensive enterprise bankruptcy threat diagnostics (Bernstein 2000; Brigham, Daves 2004; Juozaitienė 2008; Mackevičius 2008; Baldin et al. 2011; Valackienė 2011; Bragg 2012) are presented in Figure 5.

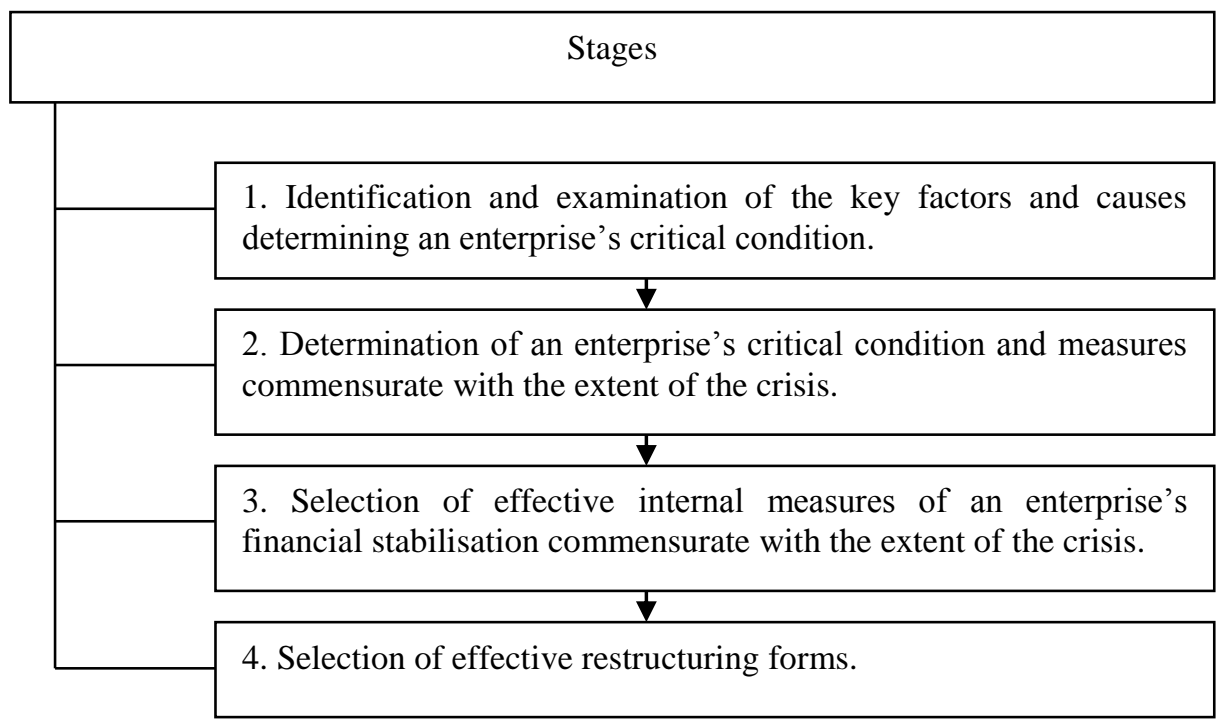

Fig.5. Main stages of comprehensive enterprise bankruptcy threat diagnostics

Source: compiled by the author

1. Identification and examination of the key factors and causes determining an enterprise's critical condition. At this stage, factors are identified and analysed according to their main characteristics. As it has been mentioned above, the factors can be divided into two groups: independent of the enterprise's activities (external factors) and dependent on the enterprise's activities (internal factors) (Juchno, Tvaronavičienè 2004; Ginevicius et al. 2005; Stundžienè, Bliekiene 2012). The analysis of the extent of the impact of individual factors on the enterprise's critical condition allows to predict their negative trends, as negative changes in internal and external factors can 
be the cause of financial difficulties among enterprises, such as insolvency or even bankruptcy (Baldin et al. 2011; Brauer 2013). At the stage, the extent of the adverse impact of specific factors on an enterprise's financial condition is determined using the following methods (Bernstein 2000; Brigham, Daves 2004; Mackevičius 2008; Juozaitienè 2008; Giriūnas et al. 2013):

- SWOT analysis. The SWOT analysis considers the enterprise's strengths and weaknesses in relation to specific factors;

- comprehensive analysis of financial coefficients. This analysis expands the number of crisis indicators, as a number of additional financial indicators are examined with a view to ensuring the comprehensiveness of the assessment of the enterprise's condition;

- correlation analysis. This method is employed in order to determine the degree of the impact of individual factors on the enterprise's critical condition. The extent of such impact can be expressed using one or more factor regression models. The examination of the results allows for categorisation of the individual factors according to the degree of their negative impact on the financial condition of the enterprise;

- other financial and non-financial methods.

2. Determination of an enterprise's critical condition and measures commensurate with the extent of the crisis. Measures of overcoming the enterprise's critical condition are described in detail depending on the extent of the enterprise's crisis, with account taken of the trends and forecasts concerning the key factors affecting the threat of bankruptcy (Grigaravičius 2003; Korotkova 2009; Vendramin et al. 2010; Bivainis, Garškaitė-Milvydienė 2011). Having regard to these conditions, it is possible to identify three principal ways of responding to the crisis which would be commensurate with the extent of the enterprise's crisis: restoration of the enterprise's solvency; restoration of the enterprise's financial stability (to achieve the enterprise's financial balance in the short term); modification of the enterprise's financial strategy in order to maintain the enterprise's economic growth (to achieve the enterprise's financial balance in the long run).

3. Selection of effective internal measures of an enterprise's financial stabilisation commensurate with the extent of the crisis. Internal financial stability measures must ensure prompt and effective solutions with a view to restoring the enterprise's solvency and financial balance through the use of internal resources. The enterprise's possibilities to neutralise the threat of bankruptcy by using the enterprise's internal financial potential depend on how quickly and to what extent the enterprise can (Brigham, Daves 2004; Mackevičius 2008; Juozaitienè 2008; Dallas 2012; Krušinskas 2013):

- ensure the growth of cash flows;

- reduce total financial liabilities;

- reduce running costs, etc.

The enterprise's possibilities to neutralise the threat of bankruptcy can be assessed by means of the above methods forecasting changes in their coefficients. Internal financial stabilisation measures are based on the consistent application of the models of appropriate management solutions depending on the specific features of the enterprise's economic activity and the scale of the crisis.

4. Selection of effective forms of an enterprise's restructuring. If the extent of the crisis of an enterprise is such that it cannot be overcome by employing internal financial stabilisation measures, then the enterprise is forced to search for external assistance. In such cases, restructuring is usually needed. The selected form of restructuring must be effective so that the enterprise's financial stability could be restored and bankruptcy could be prevented with the shortest possible period of time.

Based on results of comprehensive enterprise bankruptcy threat diagnostics, the extent of the crisis (the actual stage of the crisis) and the method of overcoming an enterprise's critical condition are finally determined (Brigham, Daves 2004; Baldin et al. 2011; Bivainis, Garškaitè-Milvydienè 2011; Brauer 2013) (Table 1).

Comprehensive enterprise bankruptcy threat diagnostics allows for obtaining a sufficiently clear view of an enterprise's critical condition in determining the scope of the problem (stage of the crisis) as well as providing for the necessary assistance measures and their implementation. High priority must be given to the implementation of the measures specified/selected for the purpose of overcoming the critical condition of the enterprise and control of its results. 
Table 1. Extent of an enterprise's crisis and potential solutions

\begin{tabular}{|l|l|l|}
\hline $\begin{array}{c}\text { Threat of bankruptcy } \\
\text { based on the results of } \\
\text { diagnostics }\end{array}$ & \multicolumn{1}{|c|}{$\begin{array}{c}\text { Stages of an } \\
\text { enterprise's crisis }\end{array}$} & \multicolumn{1}{|c|}{ Ways of overcoming an enterprise's critical condition } \\
\hline Possible & Minor financial crisis & Normalisation of current financial activities \\
\hline High & Severe financial crisis & $\begin{array}{l}\text { Use of all internal measures for the purpose of financial } \\
\text { stabilisation of an enterprise }\end{array}$ \\
\hline Very high & Financial catastrophe & $\begin{array}{l}\text { Application of effective forms of restructuring (in the event } \\
\text { of a failure - liquidation) }\end{array}$ \\
\hline
\end{tabular}

Source: compiled by the author

A timely and comprehensive diagnostics of bankruptcy threat can help to prevent the crisis or even bankruptcy, as it helps to effectively manage an enterprise's financial resources. Based on the results of bankruptcy threat diagnostics, investment and financial decisions are adopted, assessing the resources available the enterprise are assessed, the trends of their use are identified, and forecasts of the further development of the enterprise are developed. The enterprises with well-organised analytical activities can detect the imminent crisis, offer a faster response and reduce its likelihood.

\section{Possibilities of overcoming the critical condition of enterprises}

The scientific literature examining anti-crisis management and its measures stresses the role and importance of the time factor (Grigaravičius 2003; Aleksandrov 2010; Dallas 2012; Brauer 2013). In this context, the development and implementation of the measures designed to mitigate and overcome a crisis can be regarded as real-time corporate governance in the event of the crisis. Such a situation is characterised by an intense and rapid application of certain measures which could help overcome the critical situation arising in an enterprise.

Attention is focused on the issues typical of such a situation with a view to ensuring prompt implementation of targeted measures. Scientific literature identifies two types of anti-crisis management: reactive anti-crisis management (in the short term) and preventive anti-crisis management (in the long term), which are characterised by different measures and procedures for overcoming the crisis (Brigham, Daves 2004; Ginevičius et al. 2005; Mackevičius 2008; Baldin et al. 2011; Dallas 2012). In the opinion of other authors, the anti-crisis measures used by enterprises depend on a pre-defined concept of overcoming of a crisis. When developing the concept of overcoming of an enterprise's crisis, approach to the crisis is of much importance. Two approaches to crisis prevail (Sakalas, Savanevičienė 2003; Aleksandrov 2010; Radionova 2011; Valackienė 2012; Brauer 2013):

- focus on survival (which corresponds to reactive anti-crisis management);

- focus on a new condition, renewal (which corresponds to preventive anti-crisis management).

Reactive anti-crisis management (Figure 6) stands for the planning and implementation of certain measures aimed at restoring an enterprise's solvency and normal functioning in order to bring back, within the shortest possible time, the pre-crisis financial condition of the enterprise. The lack of time, caused by the negative consequences of delay, forces the enterprise to limit itself to basic measures, without linking them with the enterprise's strategic goals and objectives.

When considering the approach according to which the focus is on survival, the crisis is perceived as a threat and assumption of collapse (Grant 2003; Brigham, Daves 2004; Valackiene 2012; Dallas 2012). Such a negative perspective of the crisis determines the choice of appropriate measures intended to restore the enterprise's precrisis condition. 


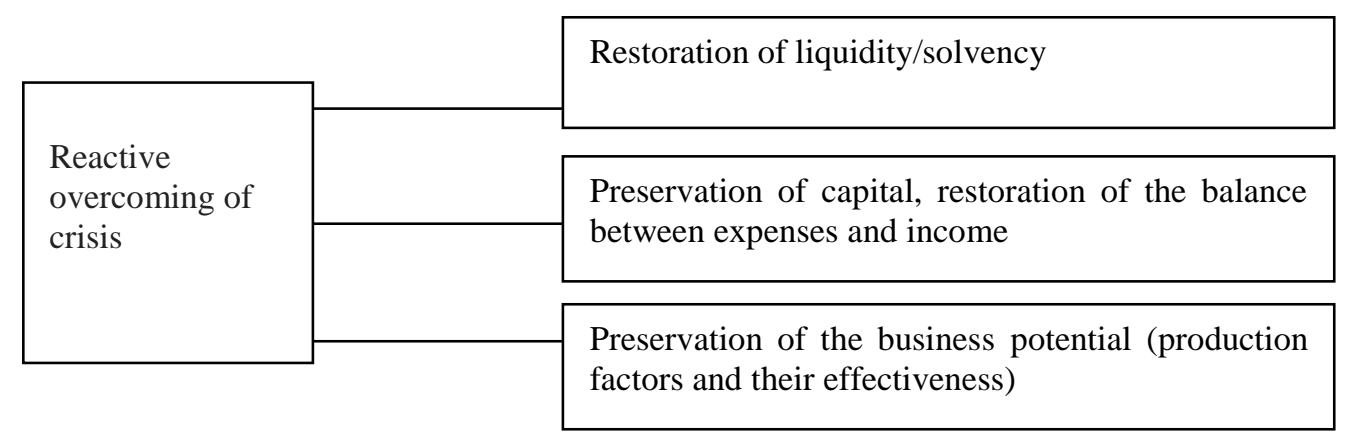

Fig.6. Components of reactive anti-crisis management

Source: compiled by the author

Preventive anti-crisis management (Figure 7) stands for the determination and implementation of a totality of the long-term goals of en enterprise and the objectives and measures intended to implement such goals in order to maintain the financial stability of the enterprise for a long period of time. When considering the approach according to which the focus is on a new condition (renewal), the crisis is perceived as the necessity of renewal, transformation of the enterprise's strategy, elimination of irrational factors, and substantiation the goals and the actions aimed at implementing them (Grant 2003; Brigham, Daves 2004; Valackienè 2012; Brauer 2013). The measures used for this purpose are treated as positive changes in an enterprise's strategy, rather than a means of combating the crisis.

\begin{tabular}{|l|l|}
\hline \multirow{2}{*}{\begin{tabular}{l} 
Preventive $\begin{array}{l}\text { overcoming of } \\
\text { crisis }\end{array}$ \\
\cline { 2 - 3 }
\end{tabular}} & $\begin{array}{l}\text { Risk management (early identification, assessment } \\
\text { and overcoming of an enterprise's critical } \\
\text { condition) }\end{array}$ \\
\cline { 2 - 2 } & $\begin{array}{l}\text { Creation of adaptive features (increase of security } \\
\text { by enhancing the ability to adapt) }\end{array}$ \\
\hline
\end{tabular}

Fig.7. Components of preventive anti-crisis management

Source: compiled by the author

Practice shows that when enterprises find themselves in a critical condition, the owners of the enterprises undertake different actions. Sometimes, the owners seek to sell an enterprise in whole or in certain parts. In other cases, the owners of the enterprise attempt to develop and implement an effective anti-crisis programme providing for a complex of measures to effectively restore the functioning of the enterprise. Various aspects of the treatment of enterprise anti-crisis management and potential different approaches to the crisis create the need to focus on different anti-crisis management measures (Grant 2003; Brigham, Daves 2004; Ginevičius et al. 2005; Korotkova 2009; Aleksandrov 2010; Fosberg 2012; Ginevičius, Podviezko 2012; Valackienė 2012; Brauer 2013). They can be of a quantitative or qualitative character or some combination of both of these characters. In scientific literature, anti-crisis management measures are often associated with the content of changes, for example, five types of changes in the activities of enterprises are often distinguished (Figure 8) (Grant 2003; Brigham, Daves 2004; Ginevičius et al. 2005; Mackevičius 2008; Korotkova 2009; Aleksandrov 2010; Fosberg 2012; Brauer 2013).

First type - increase or decrease, i.e. quantitative changes without qualitative transformations. Most heads of enterprises focus on a fall in demand and accordingly - a decrease in sales. They perceive quantitative changes as the solution of such a situation and do not provide in their decisions for any qualitative changes in an enterprise's activities. According to the economic theory, the minimum breakeven production volume can be calculated depending on the ratio of fixed costs to variable costs and output prices. The use of traditional 
methods of cost reduction (for example, reduction of the number of employees, renting unused premises, etc.) can change the breakeven point within certain limits, i.e. increase profitability of production by reducing production costs without qualitative changes: without changing the nature of activities, ways of implementation, etc. The outcome may in some cases improve the enterprise's financial condition in the short term so that it would be possible to implement qualitative changes at a later stage, when the enterprise no longer is in the critical condition (Ginevičius et al. 2005).

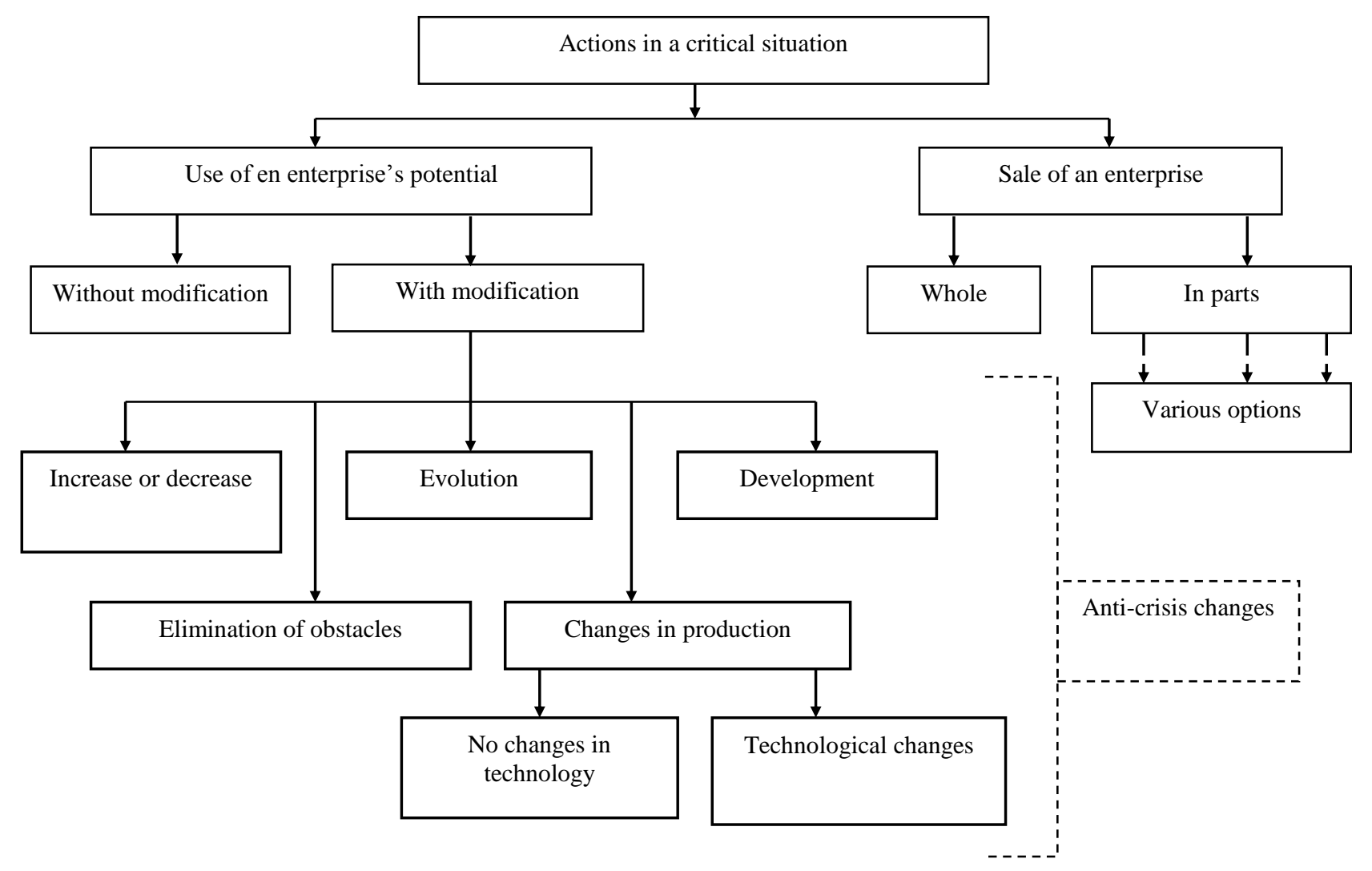

Fig.8. Available types of anti-crisis changes in enterprises' activities

Source: compiled by the author

Second type - elimination of obstacles. It is most often used in the situations which are characterised by financial problems of a temporary nature caused by unforeseen factors. Such factors can be internal or external (Ginevičius et al. 2005; Mackevičius 2008, 2011; Korotkova 2009; Radionova 2011; Brauer 2013). Elimination of obstacles is a traditional management measure which creates preconditions for the restoration of the normal functioning of en enterprise, at least for a certain period of time. The content of this type, just as the first type of changes, is quite simple, and in practice stereotypical solutions have been formed.

Third type - evolution, i.e. qualitative changes taking place due to natural causes, such as the creative activity of employees, rather than through the active intervention of managers. Evolution is usually more productive in small enterprises, in the early stages of their functioning, when their members have new ideas yet to be implemented and are active without any incentives. When certain activity stereotypes are formed within a team, creative flight gives way to conservatism. The enterprise enters the maturity stage and, if further evolutionary changes face obstacles, the stage of maturity moves to the decline stage, because the formed stereotypes cease to follow changes in the external environment. Among the reasons underlying evolutionary processes, researchers often indicate the physical and moral deterioration of fixed capital, inflation, changes in the market situation, and etc. Most of them can lead to destructive changes. 
Changes of the three types mentioned above are attractive in that they do not require major investments. They are most often implemented by using available resources, although certain investments are sometimes necessary too.

Fourth type - changes in production. Two key known versions of this type differ in whether the current technological potential is maintained or changed (Grant 2003; Brigham, Daves 2004; Ginevičius et al. 2005; Korotkova 2009; Brauer 2013). In the first case, the nature of an enterprise's activities changes by using the existing productive potential. It is recommended to use optimisation methods in order to find the most appropriate areas of activities. It should be noted that design optimisation requires extensive marketing research, improvement of the organisational structure, and qualified management potential. It is necessary to create, within the structure of enterprise management, a professional and influential marketing department closely cooperating with technological departments and capable of affecting the nomenclature and quality of released products and the efficient distribution of the products in the market. This variant is characterised by a shift in the focus of an enterprise from production to the market without any major technological changes taking place.

In the latter case, an enterprise is redesigned by fundamentally changing the production potential. This option requires large investment, radical organisational and management solutions and appropriate personnel training policy. In order to identify effective production change options, it is necessary to develop and assess a number of different projects (assessing the implementation period, the payback period, profitability, etc.).

Fifth type - the development process. Preconditions for this process are created by changes brought about within an enterprise on a positive initiative of the staff (not only top managers, but also other employees) (Brigham, Daves 2004; Ginevičius et al. 2005; Aleksandrov 2010; Brauer 2013). The changes are initiated by analysing the situation, the existing business stereotypes, the physical, human, intellectual, financial, energy, and information resources being used and providing for the measures designed to eliminate obstacles and other negative factors. Organisation of the development process is one of the most complex activities requiring concerted action of formal and informal bodies and involvement of specific consultants (experts). It is necessary to develop adaptive elements allowing to adapt to the changing situation and to make economic use of own resources, including investment.

\section{Conclusions}

Recently, increasing attention is being given to anti-crisis management. Most authors share the view that anticrisis management must find its 'niche' in the general theoretical framework of corporate governance, although anti-crisis management itself is treated differently. A systemic treatment of the concept is the most comprehensive one and claims that anti-crisis management is a complex of mutually interacting actions ranging from assessments of an enterprise's financial condition and crisis diagnostics to selection and application of special measures to overcome the critical condition.

The concept of enterprise anti-crisis management is associated with the concept of enterprise restructuring, because these processes pursue nearly the same goals of ensuring that an enterprise overcomes the crisis, survives and continues to operate successfully. Restructuring often means various actions designed to revive an enterprise's activities, restore its solvency and rationalise the enterprise's operations in order to enhance the enterprise's competitiveness and adaptability to changing conditions. The mentioned actions are most frequently associated with a change in economic activities of enterprises, improvement of the organisation of operations, modernisation of production, sales of an enterprise's assets or a part of the assets, taking over of other enterprises' assets by way of merger or splitting, changes in the amount of the enterprise's obligations to its creditors and time limits for discharge of the obligations, and implementation of other technical, economic and organisational measures.

Enterprise anti-crisis management pursues the aim of timely diagnosing the threat of enterprise bankruptcy and the extent of the critical condition and developing and implementing appropriate measures intended to overcome the critical condition of an enterprise and restore its solvency and financial stability. To this end, the enterprise, relying on the main principles of anti-crisis management, develops a specific action plan that meets the stages of 
the enterprise's anti-crisis management. Anti-crisis management is based on the relevant principles and stages which distinguish anti-crisis management from ordinary corporate governance.

Anti-crisis management is different from corporate governance under normal conditions, when management measures and methods are generally intended to maintain and develop the activities of an enterprise. Anti-crisis management measures are intended not only to avoid a critical situation, but also to overcome the existing crisis, hence their content and implementation are specific. Enterprise anti-crisis management tolerates certain losses, provided they help to restore the solvency of the enterprise 'today'.

The essence of enterprise anti-crisis management lies in the development and implementation of a complex of measures. Anti-crisis management measures are developed and implemented primarily using the internal capabilities of an enterprise. In the cases when the enterprise's internal resources prove to be insufficient to restore the condition of the enterprise, it is necessary to search for external sources of funding. In general, with a view to developing and implementing anti-crisis management actions intended to eliminate the threat of bankruptcy, normalising the enterprise's economic activities and financial condition, the measures applied by enterprises depend on the concept of mitigation of the crisis which has been developed in advance: either focusing on survival or focusing on a new condition and renewal.

Both in scientific literature and in practice, it is pointed out that when enterprises find themselves in a critical situation, enterprise anti-crisis measures are different. Anti-crisis management measures may be of a quantitative or qualitative character or a combination of both of such characters. Anti-crisis management measures are often associated in scientific literature with significant changes. In all cases, enterprises attempt to develop and implement an effective anti-crisis programme providing for a complex of measures to restore the effective functioning of the enterprise.

\section{References}

Aleksandrov, G.A. 2010. Crisis management: theory, practice, infrastructure. Moscow. 544 p. (in Russian)

Altman, E. I.; Hotchkiss, E. 2006. Corporate Financial Distress and Bankruptcy: Predict and Avoid Bankruptcy, Analyse and Invest in Distressed Debt. Third Edition. New York: Wiley Finance.

Baikovs, A.; Zariņš, I. 2013. Philosophical, legal and general issues of legal liability, Entrepreneurship and Sustainability Issues 1(1): 23-36 DOI: http://dx.doi.org/10.9770/jesi.2013.1.1(3)

Baldin, K.V.; Bystrov, O.F.; Rukosuev, A.V. 2011. Crisis management: macro-and micro-level. Moscow. 316 p. (in Russian)

Bernstein, L. 2000. Analysis of Financial Management. McGraw-Hill. 367 p.

Bivainis, J.; Garškaitė-Milvydienè, K. 2011. The System of Diagnostics of Bankruptcy Threat to the Enterprises, Verslas: teorija ir praktika [Business: theory and practice] 11(3): 204-212.

Bragg, S. M. 2012. Financial analysis: a controller's guide. Wiley. 416 p. SBN: 978-1-118-42892-4

Brauer, M. F. 2013. The effects of short-term and long-term oriented managerial behaviour on medium-term financial performance: longitudinal evidence from Europe, Journal of Business Economics and Management 14(2): 386-402.

Brigham, E. F.; Daves, P. R. 2004. Intermediate Financial Management. USA, Thomson, South-Western. 230 p.

Dallas, L. 2012. Short-termism, the financial crisis, and corporate governance, Journal of Corporation Law 37: $264-361$.

De Alencar, L.M.; Almeida, H.N. 2013. Economic viability and sustainability of solidarity economy enterprises: a case study on the technological incubator of popular cooperatives of the Catholic University of Salvador, Entrepreneurship and Sustainability Issues 1(2):92-98. DOI: http://dx.doi.org/10.9770/jesi.2013.1.2(3)

De Pamphilis, D. M. 2010. Mergers, Acquisitions, and Other Restructuring Activities. Burlington: Academic Press.

Didenko, K.; Meziels, J.; Voronova, I. 2012. Assessment of enterprises insolvency: challenges and opportunities, Ekonomika ir vadyba [Economics and management] 17(1): 69-76. 
Dudzevičiūtè, G. 2013. Lithuanian manufacturing trends in the context of developed and developing countries, Entrepreneurship and Sustainability Issues 1(1): 55-66. DOI: http://dx.doi.org/10.9770/jesi.2013.1.1(6)

Enterprises Restrukturing Law of the Republic of Lithuania. 2001. Valstybès žinios [Official Gazette] No. 31-1012. Available from: <http://www3.lrs.lt/pls/inter3/dokpaieska.showdoc_1?p_id=377908\&p_tr2=2> (Accessed 11 April 2014)

Fosberg, R. H. 2012. Capital structure and the financial crisis, Journal of Finance and Accountancy 11: 46-55.

Gibson, C. H. 2008. Financial reporting \& analysis: Using financial accounting information. South-Western Pub.

Ginevičius, R.; Bivainis, J.; Melnikas, B.; Paliulis, N.; Rutkauskas, A.V.; Staškevičius, A. J.; Pabedinskaitė, A.; Šečkutė, L.; Tamošiūnas, A. 2005. Šiuolaikinis verslas: tobulinimo prioritetai [Modern Business: Development Priorities]. Kolektyvinè monografija [Collective Monograph]. Vilnius: Technika. 448p.

Ginevičius, R.; Podviezko, A. 2011. A framework of evaluation of commercial banks, Intellectual Economics 1(9): 37-53.

Ginevičius, R.; Podviezko, A. 2012. Sprendimų paramos metodų taikymo ypatumai vertinant finansinį komercinių bankų stabilumą [Features of Applying Decision-Making Methods to Evaluation of Financial Stability of Commercial Banks], Verslas: teorija ir praktika [Business: Theory and practice] 13(4): 314-323.

Giriūnas, L.; Mackevičius, J. 2014. Evaluation of frauds in public sector, Entrepreneurship and Sustainability Issues 1(3): 143-150. DOI: http://dx.doi.org/10.9770/jesi.2014.1.3(3)

Giriūnas, L.; Mackevičius, J.; Valkauskas, R. 2013. Analytical study and modeling of statistical methods for financial data analysis: theoretical aspect, Journal of Security and Sustainability Issues 3(1): 43-48. DOI: http://dx.doi.org/10.9770/jssi.2013.3.1(5)

Goodhart, C. A. E. 2006. A framework for assessing financial stability? Journal of Banking \& Finance 30(12): 3415-3422.

Grant, W. N. 2003. Corporate Bankruptcy. Tools, Strategies and Alternatives. John Wiley \& Sons, Inc., Hoboken, New Jersey. 280 p.

Grigaravičius, S. 2003. Imoniu nemokumo diagnostika ir ju pertvarkymo sprendimai [Corporate insolvency diagnosis and restructuring solutions]. Kaunas, VDU. 126 p.

Huang, S. M.; Tsai, C. F.; Yen, D. C.; Cheng, Y. L. 2008. A hybrid financial analysis model for business failure prediction, Expert Systems with Applications 35(3): 1034-1040.

Juchno, N.; Tvaronavičienė, M. 2004. Imoniu bankrotai Lietuvoje: priklausomybės nuo makroekonominių veiksnių tyrimas [Corporate bankruptcies in Lithuania: study of dependence on macroeconomic factors], Verslas: teorija ir praktika [Business: Theory and practice] 7: $65-72$.

Juozaitienè, L. 2008. Imonès finansai: analize ir valdymas [Corporate Finance: Analysis and Management]. Šiauliai: Šiaulių universiteto leidykla. 416 p.

Korotkova, E. M. 2009. Crisis management. Moscow. 620 p. (in Russian)

Krušinskas, R. 2013. Analysis of the impact of financial engineering tools on small and medium-sized business in Lithuania, Ekonomika ir vadyba [Economics and management] 18(3): 409-417.

Laužikas, M.; Krasauskas, A. 2013. Impacts of sustainable structural growth on the economic performance of listed companies, Entrepreneurship and Sustainability Issues 1(2): 81-91. DOI: http://dx.doi.org/10.9770/jesi.2013.1.2(2)

Laužikas, M.; Mokšeckienè. 2013. The role of creativity in sustainable business, Entrepreneurship and Sustainability Issues 1(1): 10-22. DOI: http://dx.doi.org/10.9770/jesi.2013.1(2)

Mačiulis, A.; Tvaronavičienė, M. 2013. Secure and sustainable development: Lithuania's new role in taking the Presidency of the EU, Journal of Security and Sustainability Issues 3(2): 5-13. DOI: http://dx.doi.org/10.9770/jssi.2013.3.2(1)

Mackevičius, J. 2008. Imonių veiklos analizè - informacijos rinkimo, tyrimo ir vertinimo sistema [The analysis of companies' business as a system of collection, research and evaluation of information], Informacijos mokslai [Information sciences]: (46): 46-56.

Mackevičius, J. 2011. Methodology of Complex Analysis of Tangible Long-Term Assets, Verslas: teorija ir praktika [Business: theory and practice] 9(4): 237-244. 
Mackevičius, J.; Valkauskas, R. 2010. Integruota įmonès finansinès būklès ir veiklos rezultatu analizès metodika [Methodology of the Integrated Analysis of Company's Financial Status and Its Performance Results], Verslas: teorija ir praktika [Business: Theory and practice] 11(3): 213-221.

Mažintienè, A.; Burkšaitienè, D. 2012. The need of bankruptcy prediction in the company, 7th international scientific conference “Business and Management 2012”: selected papers. Vilnius: Technika, 135-141.

Radionova, H.V. 2011. Crisis management. Moscow. 680 p. (in Russian)

Sabonienè, A. 2007. Pramonès restruktūrizacija ir konkurencingumas [Industrial Restructuring and Competitiveness]. Kaunas: Technologija. $46 \mathrm{p}$.

Sakalas, A.; Savanevičienè, A. 2003. Imonès krizių vadyba [Enterprise Crisis Management]. Kaunas: Technologija. 202 p.

Sakalas, A.; Virbickaite, R. 2011. Construct of the Model of Crisis Situation Diagnosis in a Company, Inžinerine ekonomika [Engineering Economics] 22(3): 255-261.

Stundžienè, A.; Bliekienè. R. 2012. Ekonomikos svyravimų įtaka įmonių veiklos rezultattams [The Impact of Economic Fluctuations on Company Results], Verslas: teorija ir praktika [Business: Theory and practice] 13(1): 5-17.

Tvaronavičienè, M. 2001. Imonių bankroto proceso ekonominio efektyvumo didinimo kryptys [Magnification trends of economic efficiency of enterpriese bankruptcy], Ekonomika [Economics] 54: 135-144.

Tvaronavičienè, M. 2014. If industrial sector development is sustainable: Lithuania compared to the EU, Entrepreneurship and Sustainability Issues 1(3): 134-142. DOI: http://dx.doi.org/10.9770/jesi.2013.1.3(2)

Valackienè, A. 2011. Theoretical Substation of the Model for Crisis Management in Organization, Inžinerine ekonomika [Engineering Economics] 22(1): 78-90.

Valackienè, A. 2012. Krizių valdymas ir sprendimu prièmimas [Crisis management and decision-making]. Kaunas: Technologija. 360 p.

Valkauskas, R. 2013. Assessment of the financial position of a company: theoretical aspect, Ekonomika [Economics] 92(3) 166-80.

Vendramin, L.; Campello, R. J.; Hruschka, E. R. 2010. Relative clustering validity criteria: A comparative overview, Statistical Analysis and Data Mining 3(4): 209-235.

Vosylius, E.; Rakutis, V.; Tvaronavičienė, M. 2013. Economic growth, sustainable development and energy security interrelation, Journal of Security and Sustainability Issues 2(3): 5-14. DOI: http://dx.doi.org/10.9770/jssi.2013.2.3(1)

Wahl, M.; Prause, G. 2013. Toward understanding resources, competencies, and capabilities: business model generation approach, Entrepreneurship and Sustainability Issues 1(2): 67-80. DOI: http://dx.doi.org/10.9770/jesi.2013.1.2(1)

Kristina GARŠKAITĖ-MILVYDIENĖ works at Vilnius Gediminas Technical University, Faculty of Business Management, Department of Finance Engineering. She is Doctor of Social Sciences, Associate Professor. Research interests: financial analysis, multicriteria evaluation, restructuring and bankruptcy of enterprises, prediction of bankruptcy threat, forecasting models, anti-crisis management and its measures.

(cc) $\mathbf{E Y}$ This work is licensed under a Creative Commons Attribution 3.0 License. 